\title{
WBP1L wt Allele
}

National Cancer Institute

\section{Source}

National Cancer Institute. WBP1L wt Allele. NCI Thesaurus. Code C113283.

Human WBP1L wild-type allele is located in the vicinity of $10 \mathrm{q} 24.32$ and is approximately $72 \mathrm{~kb}$ in length. This allele, which encodes WW domain binding protein 1-like, may play a role in heme binding. 